\title{
Heterogeneity of Ribosomal Proteins among Streptomyces Species and its Application to Identification
}

\author{
By KOZO OCHI \\ Exploratory Research Laboratories, Fujisawa Pharmaceutical Co., 5-2-3 Tokodai, Tsukuba, \\ Ibaraki 300-26, Japan
}

(Received 3 April 1989; revised 12 June 1989; accepted 14 June 1989)

The ribosomal proteins from 11 Streptomyces strains representing various numerical taxonomic clusters were compared by two-dimensional PAGE. The protein patterns were specific for each species and were unaffected by acridine dye treatment, suggesting genetic stability of ribosomal proteins. An attempt was made to identify one strain of Streptomyces by both traditional taxonomic methods and analysis of the ribosomal protein patterns. Both methods identified the strain as Streptomyces lavendulae, and protein pattern analysis also showed that Streptomyces avidinii was closely related to this species. The practical application of ribosomal protein patterns in Streptomyces taxonomy was therefore demonstrated.

\section{INTRODUCTION}

Although ribosomal proteins and RNA molecules have been studied in great detail in Escherichia coli (Wittmann, 1976; Kurland, 1977; Nomura et al., 1984; Lindahl \& Zengel, 1986) and to a lesser extent in the genus Bacillus (Geisser et al., 1973b; Wienen et al., 1979), little is known about the detailed structure of ribosomes from other bacterial species. The twodimensional gel electrophoresis technique developed by Kaltschmidt \& Wittmann (1970) has been especially useful for comparison of the ribosomal proteins from different species. Geisser $e t$ $a l$. $(1973 a)$ found that the ribosomal proteins from eight species in the Enterobacteriaceae were very similar in their electrophoretic properties, and that the ribosomal proteins of several Bacillus species were also similar to one another (Geisser et al., 1973b). The use of twodimensional separation of ribosomal proteins for identification and classification purposes has been further extended to other groups of organisms such as Gram-negative bacteria (Böck, 1985), fungi (Goff \& Begueret, 1984) and mammals (Madjar \& Traut, 1980). The method was especially useful in the analysis of methanogenic bacteria for which classical identification criteria are not readily available (Böck, 1985). One-dimensional gel electrophoresis was also successfully applied to correlate the relatedness of different yeast species suggested by ribosomal protein patterns with that based on DNA-DNA homology (Adoutte-Panvier et al., 1980). Despite similarity of ribosomal protein patterns within related genera or species, studies on relC mutants of several Streptomyces species revealed considerable electrophoretic variability in the ribosomal protein patterns (unpublished data). This paper describes the results of a more systematic study of the variability of streptomycete ribosomal proteins, and discusses the applicability of such variability to the taxonomy of Streptomyces.

\section{METHODS}

Strains. The strains used are listed in Table 1. Streptomyces strain MA406-A-1 is a prototrophic wild-type strain which produces formycin (Ochi, 1986). Curing of formycin production in strain MA406-A-1 was performed by growing the cells with acriflavin as described previously (Ochi, 1986).

Abbreviations: MBA, $N$ - $N^{\prime}$-methylene-bis-acrylamide; TEMED, $N, N, N^{\prime}, N^{\prime}$-tetramethylethylenediamine. 
Table 1. Streptomyces strains used in this study

\begin{tabular}{|c|c|c|c|c|c|}
\hline Species & $\begin{array}{l}\text { Cluster } \\
\text { group }\end{array}$ & $\begin{array}{c}\text { Cluster } \\
\text { no.* }\end{array}$ & $\begin{array}{c}\text { Strain } \\
\text { no. }\end{array}$ & $\begin{array}{l}\text { Antibiotic } \\
\text { produced }\end{array}$ & Source‡ \\
\hline Streptomyces coelicolor & $\mathbf{A}$ & $1 \mathrm{~A}$ & $\mathrm{~A} 3(2)$ & Methylenomycin & JII \\
\hline Streptomyces griseus & A & $1 \mathrm{~B}$ & IFO 13189 & Streptomycin & IFO \\
\hline Streptomyces venezuelae & A & 6 & ISP 5230 & Chloramphenicol & IFO \\
\hline Streptomyces violaceus & A & 6 & ISP 5082 & Mycetin & IFO \\
\hline Streptomyces parvulus & A & 12 & ISP 5048 & Actinomycin D & IFO \\
\hline Streptomyces antibioticus & A & 31 & ATCC 14888 & Actinomycins & ATCC \\
\hline Streptomyces hygroscopicus & A & 32 & ISP 5578 & Hygromycin & IFO \\
\hline Streptomyces griseoflavus & A & 37 & FERM 1805 & Bicozamycin & FERM \\
\hline Streptomyces avidinii & $\mathbf{F}$ & 56 & ISP 5526 & Streptavidin & IFO \\
\hline Streptomyces lavendulae & $\mathrm{F}$ & 61 & ISP 5069 & Streptothricin & IFO \\
\hline $\begin{array}{l}\text { Streptomyces griseolavendus } \\
\text { (Streptomyces lavendulae } \\
\text { subsp. grasserius) }\end{array}$ & $\mathrm{F}$ & 61 & ISP 5385 & Grasseriomycin & IFO \\
\hline Streptomyces sp. & NA & NA & MA406-A-1 & Formycin & IMC \\
\hline
\end{tabular}

Identification procedures. Species were identified according to the methods of Shirling \& Gottlieb (1966). Each strain was examined for the following characters: morphology, micro-morphology, spore morphology, aerial mass colour, reverse colour, soluble colours, melanin production and carbon utilization. All characteristics were determined using ISP media 2-9 (Difco) as recommended by Shirling \& Gottlieb (1966). Inoculated media were incubated at $30^{\circ} \mathrm{C}$, and all tests were done twice to confirm reproducibility. Spore chain morphology was examined by light and scanning electron microscopy of 14-d-old cultures on ISP media 3 and 4 . Spore surface ornaments were determined on scanning electron microscopy preparations. Aerial spore-mass colour was determined with cultures on ISP media 2, 3, 4 and 5. Substrate mycelial pigments were observed after $14 \mathrm{~d}$ on ISP medium 4. The production of soluble pigments was determined on ISP medium 5 after $14 \mathrm{~d}$. Melanin production was determined on ISP media 6 and 7 after $4 \mathrm{~d}$. Carbon-source utilization was determined on ISP medium 9 supplemented with an ether-sterilized carbon source after $14 \mathrm{~d}$ and $21 \mathrm{~d}$.

Preparation of ribosomes. All of the strains were grown to mid-exponential phase (usually 10-15 h) in SPY medium (Ochi, 1987) containing a reduced amount $(0 \cdot 1 \%)$ of anhydrous $\mathrm{MgSO}_{4}$. Cells were collected on a filter paper (diameter $9 \mathrm{~cm}$, no. 2, Toyo Roshi), and washed with deionized water; the cell-paste (about $7 \mathrm{~g}$ wet weight) was then suspended in $15 \mathrm{ml}$ of buffer containing $20 \mathrm{mM}$-Tris/ $\mathrm{HCl}$ (pH 8.0), $10 \mathrm{~mm}$-magnesium acetate, $20 \mathrm{~mm}$ ammonium chloride, $5 \mathrm{~mm}$-2-mercaptoethanol and $0.1 \mathrm{~mm}$-phenylmethylsulphonyl fluoride (PMSF). The cells were disrupted by sonication for $3 \mathrm{~min}$ in an ice-cold bath. Deoxyribonuclease $\left(3 \mu \mathrm{g} \mathrm{ml}^{-1}\right.$, final concn) was then added and after $10 \mathrm{~min}$ at $0{ }^{\circ} \mathrm{C}$, cell debris was removed by centrifugation at $16000 \mathrm{~g}$ for $30 \mathrm{~min}$. Ribosomes present in the supernatant were then pelleted at $110000 \mathrm{~g}$ for $4 \mathrm{~h}$. The supernatant was discarded, and the crude ribosomes were resuspended in $15 \mathrm{ml}$ of buffer containing $20 \mathrm{mM}$-Tris/ $\mathrm{HCl}$ (pH 7.6), $10 \mathrm{mM}$-magnesium acetate, $1 \mathrm{M}$-ammonium chloride, $5 \mathrm{mM}$-2-mercaptoethanol and $0.1 \mathrm{mM}$-PMSF. After standing overnight at $4{ }^{\circ} \mathrm{C}$, the ribosomes were again pelleted by centrifugation at $110000 \mathrm{~g}$ for $4 \mathrm{~h}$, and the supernatant was discarded. The 'washed' ribosomes thus obtained were used as the 70S ribosome preparation for the subsequent experiments.

Preparation of total ribosomal proteins. Ribosomal proteins were prepared by the method of Hardy et al. (1969) with modifications as follows. The $70 \mathrm{~S}$ ribosomal preparation described above was dissolved in $2.5 \mathrm{ml}$ of a solution containing $10 \mathrm{~mm}$-Tris/ $\mathrm{HCl}$ (pH 8.0), $3 \mathrm{~mm}$-succinic acid, $10 \mathrm{~mm}$-magnesium chloride and 0.1 mM-PMSF. Then $0.25 \mathrm{ml}$ of $1 \mathrm{M}$-magnesium chloride and $5 \mathrm{ml}$ acetic acid $(99 \%)$ were added consecutively, followed by continuous stirring in an ice bath. After $45 \mathrm{~min}$ the precipitated RNA was separated from the supernatant (containing the ribosomal protein) by centrifugation at $12000 \mathrm{~g}$ for $10 \mathrm{~min}$. For further extraction of the ribosomal proteins, the precipitated RNA was dissolved in $3 \mathrm{ml} 67 \%(\mathrm{v} / \mathrm{v})$ acetic acid containing $33 \mathrm{~mm}$-magnesium chloride, and stirred for $20 \mathrm{~min}$ in an ice bath. After centrifugation at $12000 \mathrm{~g}$ for $10 \mathrm{~min}$ the supernatant was collected. The supernatants were combined, dialysed overnight against 5 litre $2 \%(\mathrm{v} / \mathrm{v})$ acetic acid, lyophilized for $20 \mathrm{~h}$ and then redissolved in $1-1.5 \mathrm{ml}$ of deionized water. A small amount of insoluble material was removed by centrifugation at $5000 \mathrm{~g}$ for $10 \mathrm{~min}$. The supernatant fluid was stored at $-20^{\circ} \mathrm{C}$ and used as the total ribosomal protein sample for gel electrophoresis. It contained 20 to $30 \mathrm{mg}^{\circ}$ protein $\mathrm{ml}^{-1}$. All the procedures used in the preparation of the ribosomes and ribosomal proteins were at $0-4{ }^{\circ} \mathrm{C}$. 
Two-dimensional PAGE. The method described by Kaltschmidt \& Wittmann (1970) was used. All the reagents were of a special grade prepared for electrophoresis. The separation gel used for the first dimension contained, per $100 \mathrm{ml}: 36 \mathrm{~g}$ urea, $4 \mathrm{~g}$ acrylamide, $0 \cdot 1 \mathrm{~g} N$ - $N^{\prime}$-methylene-bis-acrylamide (MBA), $0 \cdot 8 \mathrm{~g}$ disodium EDTA, $3 \cdot 2 \mathrm{~g}$ boric acid, $4.8 \mathrm{~g}$ Tris base and $0.3 \mathrm{ml} N, N, N^{\prime}, N^{\prime}$-tetramethylethylenediamine (TEMED). This was polymerized by

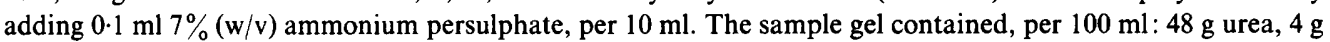
acrylamide, $0.2 \mathrm{~g} \mathrm{MBA}, 0.085 \mathrm{~g}$ disodium EDTA, $0.32 \mathrm{~g}$ boric acid and $60 \mu \mathrm{l}$ TEMED. This was polymerized by adding $0.1 \mathrm{ml}$ each of $0.5 \%$ ammonium persulphate and $0.05 \%$ riboflavin, per $10 \mathrm{ml}$. The electrode buffer used in the first dimension contained, per litre: $360 \mathrm{~g}$ urea, $2.4 \mathrm{~g}$ disodium EDTA, $9.6 \mathrm{~g}$ boric acid and $14.6 \mathrm{~g}$ Tris base. For the first dimension electrophoresis a glass tube $152 \mathrm{~mm}$ long and $5 \mathrm{~mm}$ inner diameter was used. The sample gel volumes amounted to $0 \cdot 1-0 \cdot 12 \mathrm{ml}$, and contained $400-500 \mu \mathrm{g}$ of total ribosomal protein. Electrophoresis was carried out for $30 \mathrm{~h}$ at a constant current of $2 \mathrm{~mA}$, and then the gel was dialysed immediately against $100 \mathrm{ml}$ of dialysing buffer [containing, per litre: $480 \mathrm{~g}$ urea, $0.74 \mathrm{ml}$ acetic acid $(99 \%)$ and $2.4 \mathrm{ml} 5 \mathrm{M}-\mathrm{KOH}$ ] for $1 \mathrm{~h}$. The dialysis procedure was repeated once. The dialysed gel was immediately used for the second dimension. The gel used for second dimension contained, per $100 \mathrm{ml}: 36 \mathrm{~g}$ urea, $18 \mathrm{~g}$ acrylamide, $0.5 \mathrm{~g} \mathrm{MBA}, 5 \cdot 2 \mathrm{ml}$ acetic acid ( $99 \%)$, $0.96 \mathrm{ml} 5 \mathrm{M}-\mathrm{KOH}$ and $0.58 \mathrm{ml}$ TEMED. This was polymerized by adding $3.3 \mathrm{ml} 10 \%(\mathrm{w} / \mathrm{v})$ ammonium persulphate, per $100 \mathrm{ml}$. The electrode buffer for the second dimension contained, per litre: $14 \mathrm{~g}$ glycine and $1.5 \mathrm{ml}$ acetic acid $(99 \%)$. The size of the gel slab prepared for the second dimension electrophoresis was $125 \times 138 \times 3 \mathrm{~mm}$. Electrophoresis was carried out for $20 \mathrm{~h}$ at a constant voltage of $90 \mathrm{~V}$ (initial current $22 \mathrm{~mA}$ ).

After the run, the slab was placed for $2 \mathrm{~h}$ in $150 \mathrm{ml}$ methanol/acetic acid/water $(5: 1: 5$, by vol.) containing $0 \cdot 3 \mathrm{~g}$ Coomassie brilliant blue R-250, and was then destained in $500 \mathrm{ml}$ of a solution containing $7.5 \%(\mathrm{v} / \mathrm{v})$ acetic acid and $10 \%(\mathrm{v} / \mathrm{v})$ methanol with gentle stirring for $3 \mathrm{~d}$. The solution was replaced at intervals with a fresh one.

The gels were run three or four times for each ribosomal protein sample to confirm the reproducibility of the results obtained.

\section{RESULTS}

\section{Two-dimensional PAGE of ribosomal proteins}

The ribosomal proteins of the type strains of $S$. venezuelae, $S$. violaceus, $S$. parvulus and $S$. hygroscopicus and of strains of four other species ( $S$. griseus, $S$. coelicolor, $S$. antibioticus and $S$. griseoflavus) from various numerical taxonomic clusters (Williams et al., 1983) were extracted with acetic acid and separated by two-dimensional PAGE (Fig. $1 a-h$ ). The protein patterns varied extensively among these strains. For example, it is immediately evident that at least five proteins showed considerable variation in their migration between strains, and more than ten proteins showed little variation. Few proteins appeared to be highly conserved in these eight species. This contrasts with the situation in E. coli and Proteus mirabilis where only three proteins showed little variation and other proteins had the same electrophoretic mobility (Böck, 1985).

The protein patterns of all Streptomyces strains were unaffected [Fig. 1 $(i)$, $(j)$ ] when the ribosomal proteins were prepared from cells grown to mid-exponential phase in a different medium (maltose/polypeptone/yeast extract medium; Ochi, 1986). These results also demonstrate that protein patterns are highly reproducible in different runs. Thus, the genus Streptomyces appears to have ribosomal protein patterns specific for each taxon.

\section{Identification of Streptomyces strain MA406-A-1}

Species identification of strain MA406-A-1 was attempted using the methods of Shirling \& Gottlieb (1966). Colonial growth of the strain was reddish brown (red colour-series) on most media. Substrate mycelia were brown and a diffusible pigment was not produced. Spores were produced in short open-looped or terminal spiral chains, but some spore chains were flexuous or straight. The spore surface was smooth. The strain utilized D-glucose, D-fructose, L-arabinose and D-xylose, but not raffinose, rhamnose, sucrose, D-mannitol or L-inositol. Melanin formation was positive. The organism most closely resembled $S$. griseolavendus and to a lesser extent $S$. lavendulae and $S$. avidinii. Since $S$. griseolavendus is currently regarded as a subspecies of S. lavendulae (Skerman et al., 1980), Streptomyces spp. MA406-A-1 was considered to be a variant of $S$. lavendulae (Waksman \& Curtis) Waksman \& Henrici. It should be noted that the strain differed from $S$. lavendulae or $S$. griseolavendus type cultures in its utilization of arabinose and xylose, which were not utilized by the $S$. lavendulae or $S$. griseolavendus type cultures, as determined in parallel experiments. 

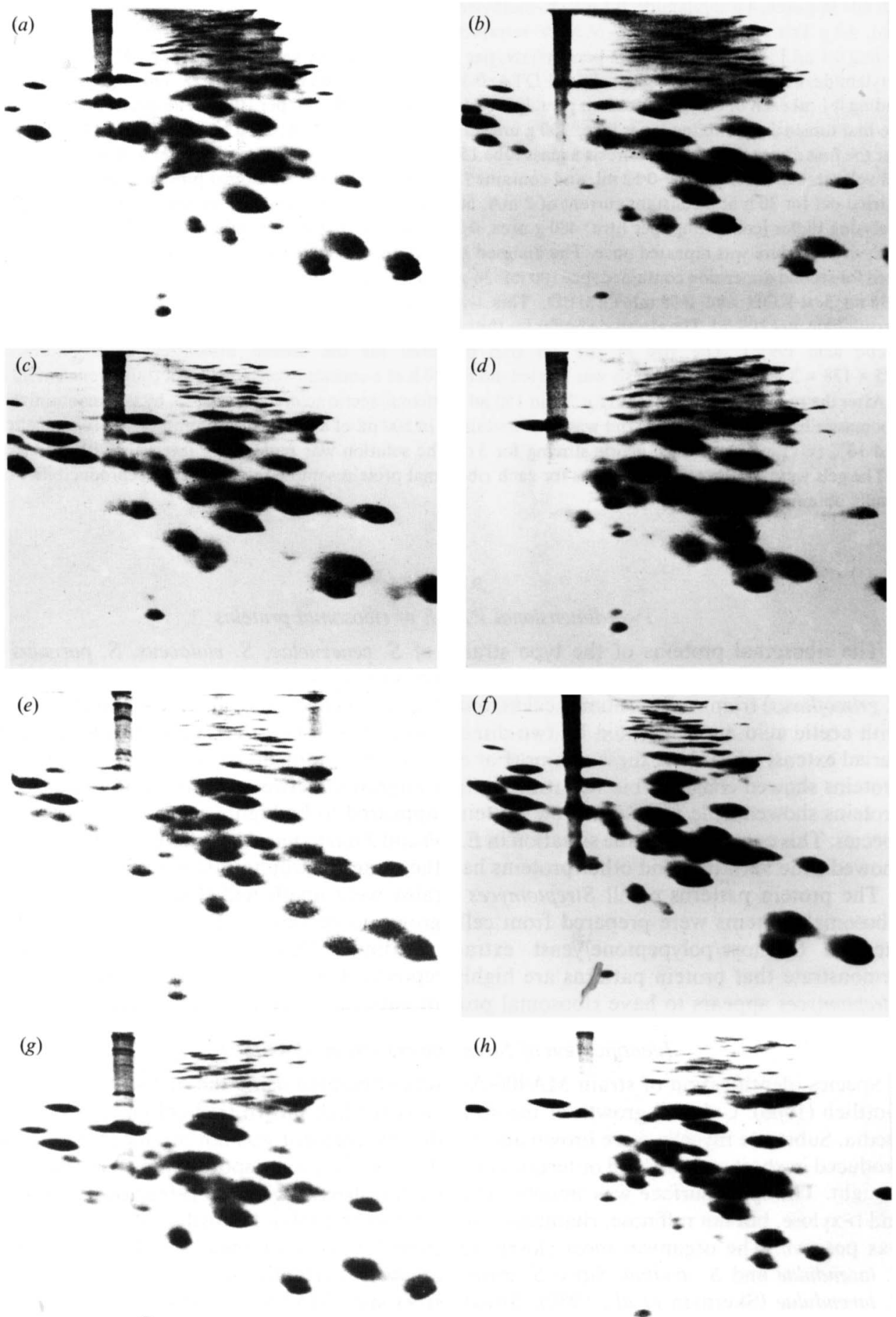

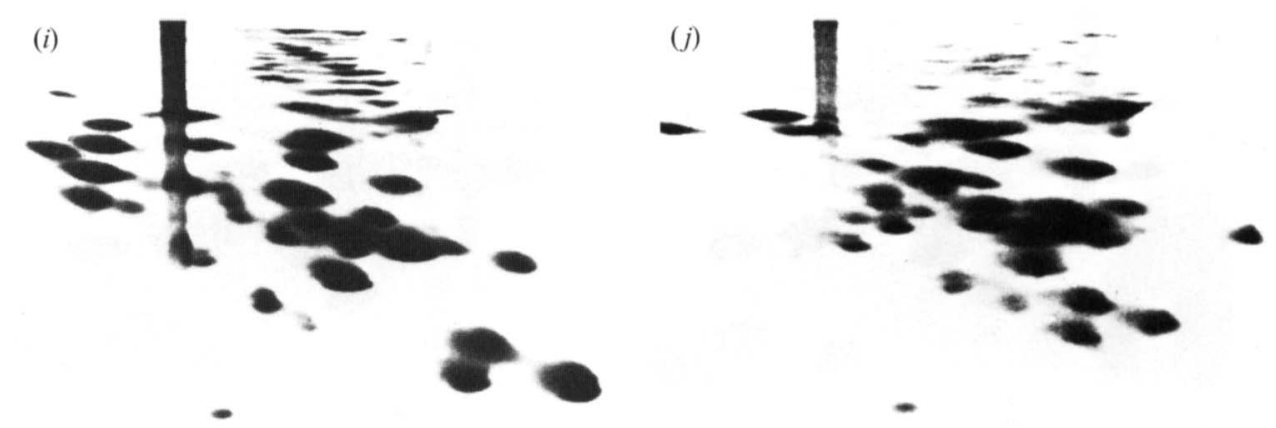

Fig. 1. Two-dimensional PAGE of total ribosomal proteins. The gel system was based upon that of Kaltschmidt \& Wittmann (1970). (a) S. venezuelae; (b) S. violaceus; (c) S. parvulus; (d) S. hygroscopicus; (e) S. griseus; ( $f$ ) S. coelicolor; $(g) S$. antibioticus; $(h) S$. griseoflavus; (i) S. coelicolor (grown in MPYmedium); (j) $S$. griseoflavus (grown in MPY-medium).

The ribosomal protein patterns of Streptomyces strain MA406-A-1, S. lavendulae, $S$. griseolavendus and $S$. avidinii were compared (Fig. $2 a-d$ ). There were extensive similarities: $S$. lavendulae and $S$. griseolavendus in particular could not be distinguished from each other. It was difficult to conclude, from these data alone, that the protein pattern of strain MA406-A-1 is closer to that of either $S$. lavendulae or $S$. avidinii. Since co-electrophoresis of mixed samples is the best comparison, ribosomal proteins from strain MA406-A-1, S. lavendulae and S. avidinii were analysed. Four proteins from strain MA406-A-1 migrated differently from those from $S$. lavendulae, and five differently from those from $S$. avidinii (Fig. $2 e, f$ ). It appears, therefore, to be difficult to identify unambiguously strain MA406-A-1 as either $S$. lavendulae or $S$. avidinii, if $S$. avidinii really represents a single taxon.

\section{Genetic stability of ribosomal proteins}

Streptomyces strains are often genetically unstable (Schrempf et al., 1988). Culture of strain MA406-A-1 with acridine dye also resulted in a high frequency (about $50 \%$ ) of colonies with altered phenotype (Ochi, 1986). Two representative mutants (derived from strain MA406-A-1 with acridine dye treatment) that had lost the ability to produce formycin, melanin pigment and aerial mycelium were analysed; there were no differences in either the number of ribosomal proteins or their mobility from those of the original strain (figures not shown).

\section{DISCUSSION}

There is a striking variability of ribosomal protein patterns among some species of Streptomyces. This was rather surprising since there are extensive similarities of ribosomal protein patterns within the Enterobacteriaceae and the Bacillaceae (Geisser et al., 1973a,b). The divergence of Streptomyces ribosomal proteins may reflect the genetic instability typical of the genus. The ribosome is essential for protein synthesis in all organisms and is presumed to have been conserved during evolution (Geisser et al., 1973a). It is therefore an excellent approach for unravelling the evolutionary relationships among organisms (briefly reviewed by Böck, 1985). In this connection, classification of actinomycetes has been attempted by partial oligonucleotide sequencing of rRNA (reviewed by Stackebrandt \& Woese, 1981 ; Goodfellow \& Cross, 1984). The results reported here suggest that the ribosomal protein pattern in twodimensional PAGE, together with the sequencing of rRNA, may offer very useful information both for classification and for identification of actinomycetes. 

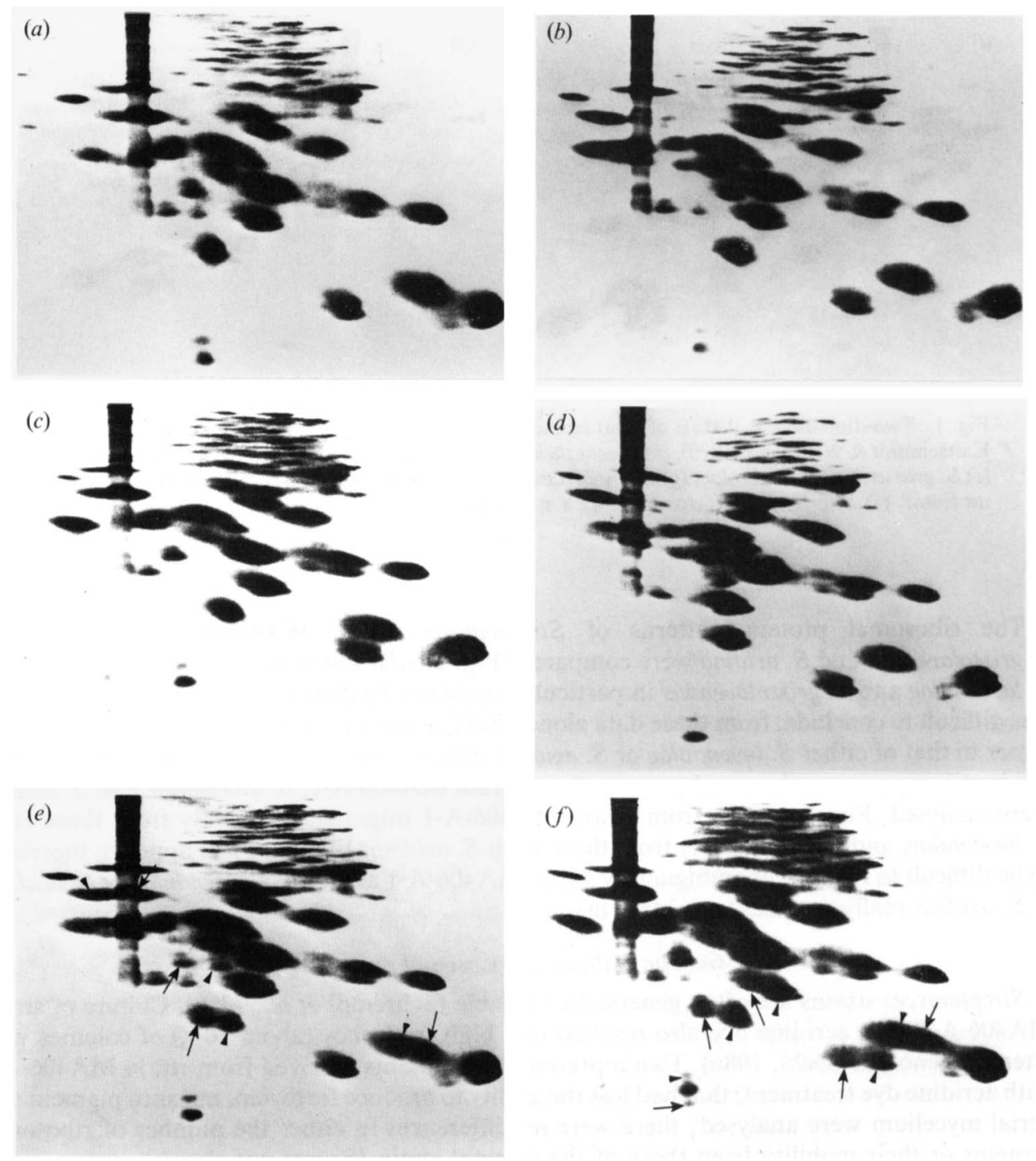

Fig. 2. Two-dimensional PAGE of total ribosomal proteins. (a) Streptomyces strain MA406-A-1; (b) S. lavendulae; (c) S. avidinii; (d) S. griseolavendus; (e) Streptomyces strain MA406-A-1 + S. lavendulae; ( $f$ ) Streptomyces strain MA406-A-1 $+S$. avidinii. Arrows indicate protein spots from Streptomyces strain MA406-A-1, and arrowheads those from $S$. lavendulae or S. avidinii.

The genus Streptomyces is of special interest because of its industrial importance. Streptomyces taxonomy has been investigated by three major approaches - morphology and pigment production, numerical taxonomy and nucleic acid hybridization - but identification has generally depended on morphology and pigment production. Recent investigations suggested an ELISA (Kirby \& Rybicki, 1986), rapid biochemical assay (Goodfellow et al., 1987) or electrophoretic movement of whole cell extracts (Dietz, 1988) as new approaches. However, sound classification and reliable identification within the genus Streptomyces are difficult because of genetic and phenetic instability. From this point of view, it can be emphasized that ribosomal protein patterns were unaffected by acridine dye treatment, which caused extensive changes in the phenotype of the tested isolates (see text). Moreover, five strains, isolated and 
identified as $S$. lavendulae in independent laboratories, all showed quite similar ribosomal protein patterns to that of the $S$. lavendulae type strain (unpublished), despite considerable differences in phenotype. In addition, the frequency of spontaneously arising relC mutants of various Streptomyces species with an altered ribosomal protein ST-L11 were quite low, i.e. $10^{-7}$ $10^{-8}$ (unpublished). This contrasts with a high frequency (usually $10^{-1}-10^{-2}$ ) of colonies arising spontaneously with a deficiency in pigment or aerial mycelium formation. More work is, however, necessary to conclude that ribosomal proteins (in comparison with other phenetic characters) are not easily affected by genetic stress. Also, although the electrophoretic comparison indicated the extent of the divergence of the ribosomal proteins within different species, it should be noted that the extent of the differences in migration does not necessarily reflect the extent of the differences in the sequences of proteins.

The great similarity of the protein patterns of $S$. lavendulae and $S$. avidinii is of interest. The degree of variation between these two species was far less than that observed in the protein patterns of $S$. venezuelae, S. violaceus, S. parvulus and S. hygroscopicus (Fig. 1). This suggests that $S$. lavendulae and $S$. avidinii are closely related species (if they do not represent a single taxon). The virtual lack of difference in the protein patterns of $S$. lavendulae and $S$. griseolavendus also supports the idea that the latter is a variant of the former. Further study of the ribosomal protein patterns within the same or different species would allow us to evaluate the efficacy of this new method as a new approach for Streptomyces (and other actinomycetes) taxonomy.

The author acknowledges $Y$. Tsurumi for his skilled assistance in obtaining electron micrographs, and Y. Okami, M. Hamada and T. Hasegawa for useful discussion.

\section{REFERENCES}

Adoutte-Panvier, A., Davies, J. E., Gritz, L. R. \& LITTLEWOOD, B. S. (1980). Studies of ribosomal proteins of yeast species and their hybrids gel electrophoresis and immunochemical cross-reactions. Molecular and General Genetics 179, 273-282.

Böck, A. (1985). Analysis of ribosomal proteins by two-dimensional gel electrophoresis. Methods in Microbiology 18, 109-122.

DiETZ, A. (1988). Practical and proposed cooperative investigational criteria for taxonomic studies of the actinomycetales. In Biology of Actinomycetes 88 (Seventh International Symposium on Biology of Actinomycetes, 1988), pp. 203-209. Edited by Y. Okami, T. Beppu \& H. Ogawara. Tokyo, Japan: Japan Scientific Societies Press.

GeIsSER, M., TischendoRF, G. W., StÖFfleR, G. \& WittmanN, H. G. (1973a). Immunological and electrophoretical comparison of ribosomal proteins from eight species belonging to Enterobacteriaceae. Molecular and General Genetics 127, 111-128.

Geisser, M., Tischendorf, G. W. \& StöfFler, G. $(1973 b)$. Comparative immunological and electrophoretic studies on ribosomal proteins of Bacillaceae. Molecular and General Genetics 127, 129-145.

GoFF, V. L. \& BeguereT, J. (1984). Immunological comparison of individual ribosomal proteins in six species of the genus Podospora. Molecular and General Genetics 193, 143-148.

Goodfellow, M. \& Cross, T. (1984). Classification. In the Biology of the Actinomycetes, pp. 7-164. Edited by M. Goodfellow, M. Mordarski \& S. T. Williams. London: Academic Press.

Goodfellow, M., Lonsdale, C., James, A. L. \& MacNamara, O. C. (1987). Rapid biochemical tests for the characterisation of streptomycetes. FEMS Microbiology Letters 43, 39-44.
Hardy, S. J. S., Kurland, C. G., Voynow, P. \& Mora, G. (1969). The ribosomal proteins of Escherichia coli. I. Purification of the $30 \mathrm{~S}$ ribosomal proteins. Biochemistry 8, 2897-2905.

KaltschmidT, E. \& WittManN, H. G. (1970). Ribosomal proteins. VII Two-dimensional polyacrylamide gel electrophoresis for finger-printing of ribosomal proteins. Analytical Biochemistry 36, 401-412.

KiRBY, R. \& RYBICKI, E. P. (1986). Enzyme-linked immunosorbent assay (ELISA) as a means of taxonomic analysis of Streptomyces and related organisms. Journal of General Microbiology 132, 1891-1894.

KuRLAND, C. G. (1977). Structure and function of the bacterial ribosome. Annual Review of Biochemistry 46, 173-200.

LINDAHL, L. \& ZENGEL, J. M. (1986). Ribosomal genes in Escherichia coli. Annual Review of Genetics 20, 297-326.

MadjaR, J. J. \& Traut, R. R. (1980). Differences in electrophoretic behaviour of eight ribosomal proteins from rat and rabbit tissues and evidence for proteolytic action on liver proteins. Molecular and General Genetics 179, 89-101.

Nomura, M., Gourse, R. \& Baughman, G. (1984). Regulation of the synthesis of ribosomes and ribosomal components. Annual Review of Biochemistry 53, 75-117.

OCHI, K. (1986). Occurrence of the stringent response in Streptomyces sp. and its significance for the initiation of morphological and physiological differentiation. Journal of General Microbiology 132, 2621-2631.

OCHI, K. (1987). Metabolic initiation of differentiation and secondary metabolism by Streptomyces griseus: significance of the stringent response (ppGpp) and 
GTP content in relation to A factor. Journal of Bacteriology 169, 3608-3616.

SChrempf, H., Dyson, P., DitTrich, W., Betzler, M., Habiger, C., Mahro, B., BröNNEKe, V., Kessler, A. \& Düvel, H. (1988). Genetic instability in Streptomyces. In Biology of Actinomycetes 88 (Seventh International Symposium on Biology of Actinomycetes, 1988), pp. 145-150. Edited by Y. Okami, T. Beppu \& H. Ogawara. Tokyo, Japan: Japan Scientific Societies Press.

Shirling, E. B. \& GotTlieb, D. (1966). Methods for characterization of Streptomyces species. International Journal of Systematic Bacteriology 16, 313340.

Skerman, V. B. D., McGowan, V. \& Sneath, P. H. A. (1980). Approved list of bacterial names. International Journal of Systematic Bacteriology 30, 225-420.
Stackebrandt, E. \& Woese, C. R. (1981). Towards a phylogeny of the actinomycetes and related organisms. Current Microbiology 5, 197-202.

Wienen, B., Ehrlich, R., StöfFler-Meilicke, M., Stöffler, G., SMith, I., Weiss, D., Vince, R. \& PestKA, S. (1979). Ribosomal protein alteration in thiostrepton- and micrococcin-resistant mutants of Bactillus subtilis. Journal of Biological Chemistry 254, 8031-8041.

Williams, S. T., Goodfellow, M., Alderson, G., Welington, E. M. H., SNeath, P. H. A. \& Sackin, M. J. (1983). Numerical classification of Streptomyces and related genera. Journal of General Microbiology 129, 1743-1813.

WitTMANN, H. G. (1976). Structure, function and evolution of ribosome. European Journal of Biochemistry 61, 1-13. 